\title{
LSM14A Gene
}

National Cancer Institute

\section{Source}

National Cancer Institute. LSM14A Gene. NCI Thesaurus. Code C122884.

This gene plays a role in the storage of mRNA. 